\title{
О СООТНОШЕНИИ ВИЗАНТИЙСКОЙ И ЗАПАДНОЙ ЛОГИЧЕСКИХ ТРАДИЦИЙ
}

Аннотаиия. В статье исследуется малоизвестное произведение византийской литературы XIII в. - учебник по логике Никифора Влеммида, выдающегося деятеля периода Никейской империи, особого периода истории Византии, начавшегося после завоевания Константинополя латинянами. Никифор Влеммид (1197 - ок. 1272) - философ, ритор, богослов и педагог. Трактат «Сокращенная логика» на греческом языке анализируется в статье с целью выявления источников данного сочинения и его влияния на развитие логики на Востоке и на Западе.

Для подробного анализа в данной статье выбран один из главных разделов схоластической логики - учение о категорическом силлогизме. Изложение этого учения у Влеммида имеет свои отличия. Во-первых, рассматриваются только три фигуры с 14, а не с 19 правильными модусами, как это имело место в латинских учебниках XIII в. Во-вторых, изложение сопровождается греческими буквенными обозначениями и графическими изображениями модусов силлогизма. В трактатах латинских авторов такой графической разработки учения о категорическом силлогизме не встречается. Правда, подобные рисунки обнаружены нами у Георгия Трапезундского (1395, Крит - приблизительно 1473, Рим). Георгий Трапезундский принадлежит к числу тех греков, которые ушли из распадающейся Византии и пришли на Запад, обогатив его культурой Востока и став первыми представителями итальянского Возрождения. Его «Диалектика», написанная в 1439-1440 гг. стала, как считают, первым в истории Ренессанса учебником по логике. Написал он его на латинском языке, но пользовался, судя по тексту, наряду с латинскими источниками, греческими рукописями.

На основе изучения «Логики» Влеммида делается вывод о том, что трактат Никифора Влеммида в наименьшей степени несет следы западного влияния (учебников У. Шервуда, Петра Испанского и др.). Выдвигается предположение о том, что аристотелевское учение о категорическом и гипотетическом силлогизмах было разработано перипатетиками и александрийскими неоплатониками, унаследовано византийскими логиками и лишь в дальнейшем получило свое завершение на Западе.

Ключевые слова: логика в Византии, Никифор Влеммид, категорический силлогизм.

\section{Larisa Tonoyan}

\section{ON THE CONNECTION BETWEEN BYZANTINE AND WESTERN LOGICAL TRADITIONS}

Abstract. The article explores a little-known work of Byzantine literature of the $13^{\text {th }}$ century, a textbook on logic by Nikephoros Blemmydes, an outstanding figure in a special period in the history of Byzantium, the period of the Nicene Empire, which arose after the conquest of Constantinople by the Latins. Nikephoros Blemmydes (1197-c. 1272) was a philosopher, rhetorician, theologian and teacher. A treatise Epitome logica in Greek is analyzed in the present article in order to identify the sources of this work and its influence on the development of logic in the East and in the West.

1 Тоноян Лариса Грачиковна - кандидат философских наук, доцент кафедры логики Санкт-Петербургского государственного университета.

Larisa G. Tonoyan, PhD, docent, Department of Logic, Saint Petersburg State University. tonoyan2003@list.ru

2 Исследование осуществляется в рамках проекта РФФИ № 18-011-00669 «Риторические стратегии в истории византийской литературы». 
For a detailed analysis in this article, one of the main sections of scholastic logic is chosenthe doctrine of the categorical syllogism. The presentation of this doctrine by Nikephoros Blemmydes has its peculiarities. First, only three figures with 14, and not 19, correct modes are presented. Second, the presentation is accompanied by Greek lettering and graphic images of the modes of syllogism. In the treatises by Latin authors such a graphic development of the doctrine of categorical syllogism has not been found by us. However, similar patterns were discovered by us in George of Trebizond (1395, Crete-approx. 1473, Rome). George of Trebizond was one of those Greeks who left the decaying Byzantium and came to the West, enriching it with the culture of the East and becoming the first representatives of the Italian Renaissance. His "Dialectics", written in 1439-1440, is believed to have become the first textbook on logic in the history of the Renaissance. He wrote it in Latin, but used, as we can see from the text, along with Latin textbooks, mainly Greek manuscripts.

Based on the study of the "Logic" of Nikephoros Blemmydes, the conclusion is drawn that the treatise by Nikephoros Blemmydes is least likely to bear traces of Western influence (textbooks by W. Sherwood, Peter of Spain, etc.). It is suggested that the scholastic doctrine of categorical and hypothetical syllogisms was developed by peripatetics and Alexandrian neoplatonists, inherited by Byzantine logicians, and only later underwent its final development in the West.

Keywords: logic in Byzantium, Nikephoros Blemmydes, categorical syllogism.

В отличие от тщательно исследованной западной средневековой логики, византийские трактаты по логике остаются до сих пор малоизвестными. Среди византийских источников XIII в. мы выделим сочинения выдающего деятеля Никейской Империи, философа, ритора, богослова, поэта, педагога - Ники-

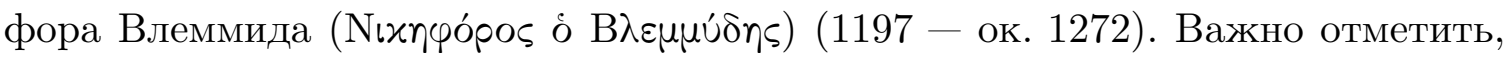
что Никифор жил в годы, когда его родной город Константинополь был занят латинянами (1204-1261). Реакция против латинского завоевания привела к тому, что византийцы стали чувствовать себя настоящими греками; они уже называли себя не «ромеями», а эллинами. Никейский император Иоанн III Ватац (1222-1254 гг.) с гордостью говорил о своем эллинском происхождении, а его преемник Феодор II Ласкарис (1254-1258 гг.) считал свою империю эллинской землей. Влеммид также высоко ценил греческую античную культуру. Изложим его биографию подробнее, поскольку имя его остается малоизвестным даже в философских кругах.

Влеммид родился в 1197 г. в Константинополе, но в 1204 г. вместе с родителями вынужден был покинуть его. Он начал учиться вначале в Никее, временно ставшей столицей части Византийской империи. В дальнейшем основал свою школу-монастырь недалеко от Эфеса, где и были написаны основные его учебные труды, из которых самыми популярными стали пособия по логике и физике.

Никифор Влеммид получил поистине эллинское образование. Много сведений об образовании и воспитании византийцев можно почерпнуть из сочинений Никифора, в частности из двух его «Автобиографий». На примере самого Никифора мы узнаем, где и когда византийцы получали логические знания. Никифор пишет о начале своего образования следующее: «После 
грамматики я приобщился к поэмам Гомера, к другим поэтам и к афтониевым прогимнасматам и к „Риторике“ Гермогена, а в философии, когда прошли шесть сверх десяти лет от моего рождения, или что-то около этого, я попробовал науку логики. Выучив „Звуки“, „Категории“ и „Искусство истолкования“, я стремился к еще более высокому совершенству в искусстве риторики, но у меня не было руководителя. Вместе с этим я занимался также врачебным искусством и умозрительно и практически. Ведь это было занятием отца, которое кормило меня семь лет» (Никифор Влеммид 1969: 325).

Дальнейшее обучение логике и наукам квадривиума Влеммид проходил у ученого Продрома в Скамандре. После арифметики, геометрии, астрономии, пишет он, «...я начинаю мучиться над силлогистикой, и, пройдя в ней надлежащий курс упражнений (ведь я был в силлогистике первым, как и в искусстве слова самым искушенным), я перехожу к физике. Я прошел ее до конца, ведь я умел уже двигаться вперед, пользуясь только комментариями и справочниками. Затем я сделал своей заботой составление речей - учебных, асклепиадовских, надо ли перечислять их? - и беру в руки святые книги, вдохновленные Божьим Духом...» (Никифор Влеммид 1969: 326-327).

В 1235 г. Никифор становится монахом. В 1237 г., после путешествия в Палестину и в другие страны, Никифор в монастыре св. Григория Чудотворца основал школу, в которой он стал «учителем философии». У Влеммида было много учеников, к примеру историк Георгий Акрополит. Но самым известным его учеником, которого он обучал в течение нескольких лет, был будущий император Феодор Ласкарис, который многие годы и после обучения с большим почтением и благодарностью относился к Никифору. Императорский двор во главе с Феодором II Ласкарисом в те годы стал центром интеллектуальной жизни Никейской империи. Однако Никифор в 1248 г. удалился в построенный на свои средства монастырь в Имафиях недалеко от Эфеса, где преподавал и писал руководства по логике и многим другим наукам.

Ради уединения и ученых занятий он отказался от епископства и патриаршего сана, несмотря на настоятельные уговоры императора. Был смел и принципиален, о чем говорит случай с фавориткой императора. Когда она прибыла с большой свитой в монастырь Влеммида, он повелел закрыть перед прибывшими людьми ворота.

В вечном споре между сторонниками Аристотеля и Платона Влеммид выбрал Аристотеля, испытав при этом немалое влияние неоплатонизма. Можно заметить сходные черты в биографии Влеммида и Аристотеля, конечно же, не сопоставляя их значимость для истории: оба они из семьи врача, оба на протяжении нескольких лет являлись учителями и воспитателями будущего правителя страны, оба основали свою школу, где писали учебные пособия по самым разным наукам и т. д. 


\section{«Сокращенная логика» Никифора Влеммида}

В описываемый период на Западе происходит расцвет латинской схоластики. «Суммулы логики», приписываемые Петру Испанскому (1220-1277), папе римскому Иоанну XXI, получают весьма широкое распространение.

Почти таким же известным учебником, по которому обучалось и воспитывалось множество византийцев, была «Сокращенная логика» Никифора Влеммида, исследование которой позволяет нам составить хорошее представление о логико-риторическом образовании в Византии XIII в.

Трактату предпослано Предисловие. Из него мы узнаем, что работа написана по заказу императора Никеи, правда, имя императора Иоанна III прямо не названо.

Никифор был хорошо знаком с сочинениями александрийских неоплатоников Аммония, Филопона и др., которые служили для него образцами. Многие работы неоплатоников традиционно предваряли предисловия. Предисловие должно было учить о целях работы, настраивать на изучение науки, пробуждать благосклонность к автору и служить местом для прямого или косвенного посвящения. Предисловие к «Логике» Влеммида несколько иное. Поскольку пособие написано по заказу императора, Влеммид рассуждает здесь о том, каким должен видеть себя царь, как соотносятся власть и философия и т. д., поэтому Предисловие к «Логике» и «Физике» больше напоминает жанр «княжеского зерцала», чем введение в философское сочинение. «Княжеское зерцало» - традиционный с конца VI в., с эпохи Юстиниана, византийский жанр. «Княжеские зерцала» всегда адресовались правителям, с которыми в большинстве случаев авторы находились в личных отношениях, и имели целью обрисовать канонический, абсолютный образ идеального царя, способного адекватно понять и решить стоящие перед государством задачи. Никифор Влеммид написал даже отдельное сочинение в жанре «княжеских зерцал» - «О царской статуе» (Никифор Влеммид 2003).

Перескажем основные мысли Предисловия: 1) логика приносит пользу для понимания Священного Писания; 2) философское познание необходимо каждому человеку и в особенности правителю; 3) царская власть и философия сходны и их совмещение (согласно Платону) ${ }^{3}$ ведет к благоденствию народа; 4) умение царствовать - высшая практическая философия, ибо в этом состоит смысл всех законов и суждений; 5) философия, в свою очередь, ру-

3 Платон («Государство», 473d): «Сократ: Пока в государствах не будут царствовать философы, либо так называемые нынешние цари и владыки не станут благородно и основательно философствовать и это не сольется воедино - государственная власть и философия, и пока не будут в обязательном порядке отстранены те люди - а их много, - которые ныне стремятся порознь либо к власти, либо к философии, до тех пор, дорогой Главкон, государствам не избавиться от зол, да и не станет возможным для рода человеческого и не увидит солнечного света то государственное устройство, которое мы только что описали словесно» (Платон 1971: 275). 
ководит всеми другими науками и искусствами; 6) автор не чувствует себя вполне компетентным в логике, но постарался, в т. ч. для учеников своей школы, выполнить заказ царя должным образом (Nikephoros Blemmydes 1863: 687-690).

\section{Источники и состав сочинения}

Сам Никифор не указывает напрямую свои источники, однако, зная историю логики в Византии, можно их в общих чертах предположить. Одним из источников является «Диалектика» Иоанна Дамаскина. Как указывают исследователи, Никифор цитирует Дамаскина целыми фрагментами, что тогда, видимо, считалось вполне допустимым. Однако, труд Никифора, хоть и называется «Сокращенная логика», значительно превышает объем и содержа-

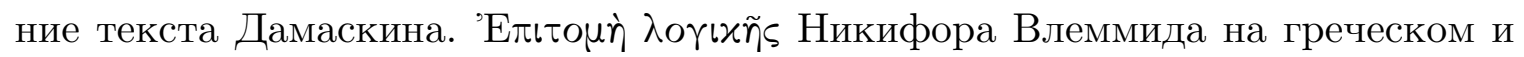
латинском языке занимает страницы с 675 по 1005 в 142-м томе греческой «Патрологии» Миня и включает в себя, кроме предисловия, 40 глав (Nikephoros Blemmydes 1863). В них излагается «Введение» Порфирия, «Категории» Аристотеля, часть трактата «Об истолковании» Аристотеля, а далее подробнейшим образом дается учение о категорических и гипотетических силлогизмах, что полностью отсутствует в «Диалектике» («Философских главах») Дамаскина. У последнего силлогизму посвящена одна небольшая глава 64 (Св. Иоанн Дамаскин 2006: 68-69). Последние главы «Соращенной логики» Никифора Влеммида построены на трактате Аристотеля «О софистических опровержениях». Мы сосредоточили свое внимание именно на тех разделах, подробное изложение которых отсутствует у Дамаскина. Данное исследование направлено на разбор учения о категорическом силлогизме.

\section{Учение о категорическом силлогизме}

Весьма обстоятельно (в главах с 31 по 36, а также в главе 40) излагает Никифор это центральное логическое учение Аристотеля. После известного аристотелевского определения силлогизма излагаются правила: общие (1. необходимо иметь одну утвердительную посылку; 2. необходимо иметь одну общую посылку) и специальные (1. для первой фигуры: меньшая посылка всегда утвердительная, большая - общая; включает все виды заключений. 2. для второй фигуры: большая посылка всегда общая; меньшая посылка или утвердительная, или отрицательная, или общая, или частная; только отрицательное заключение, общее или частное; 3. для третьей фигуры: меньшая посылка - утвердительная; большая посылка может быть любой по качеству и количеству; заключение - частное, утвердительное или отрицательное).

Первая фигура получается тогда, когда средний термин сказывается о меньшем термине, а для большего термина он подлежащее. Имеет четыре 
модуса. Первый модус - тот, который состоит из общих утвердительных посылок и общего заключения. Например:

Всякий человек - животное

Всякое животное - сущность

Следовательно, всякий человек - сущность

И далее вводятся буквенные обозначения терминов первой фигуры:

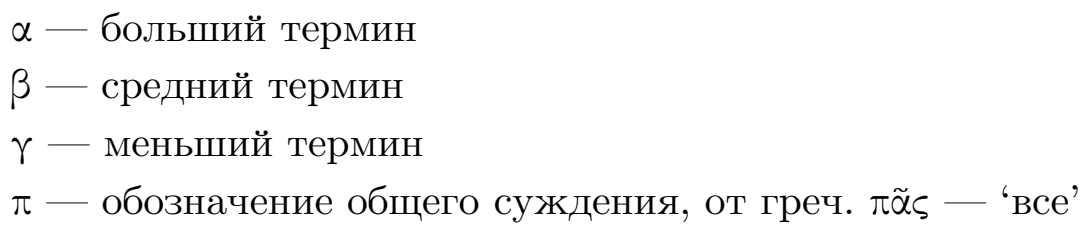

Обратим сразу внимание на схему, в которой порядок посылок иной, чем в традиционной логике: сначала идет меньшая посылка, на втором месте большая посылка.

$$
\begin{aligned}
& \gamma \pi \beta \\
& \beta \pi \alpha \\
& \gamma \pi \alpha
\end{aligned}
$$

Далее вводится рисунок для этого модуса с греческими буквенными обозначениями суждений (известного в традиционной логике как модус Barbara) (Nikephoros Blemmydes 1863: 947-948).

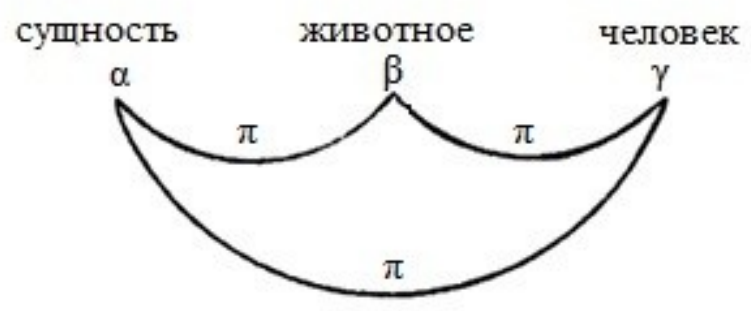

Рисунок 1

Второй модус I-й фигуры: меньшая посылка - общая утвердительная, большая посылка - общая отрицательная, заключение - общее отрицательное (Celarent):
$\gamma \pi \beta$
Всякий человек - животное
$\beta$ oט $\delta \alpha$
Всякое животное не камень
$\gamma$ oủ $\alpha$
Следовательно, всякий человек не камень

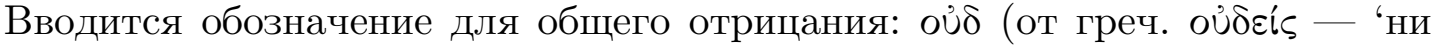
один, никакой'). 


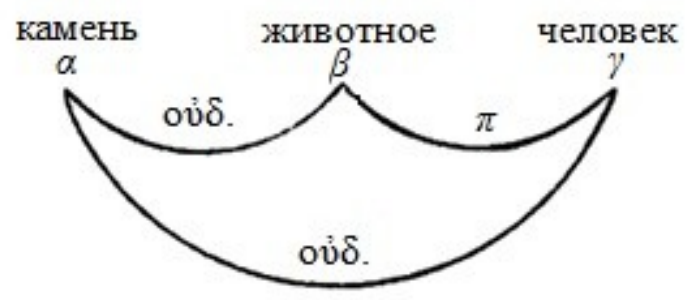

Рисунок 2

Третий модус I-й фигуры- с меньшей частноутвердительной посылкой и большей общеутвердительной (Darii):

Некое животное - человек

Всякий человек - смеющееся [существо]

Следовательно, некое животное - смеющееся [существо]

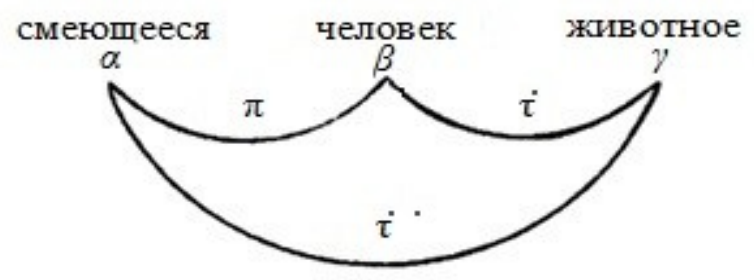

Рисунок 3

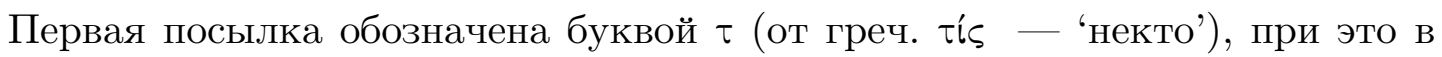
посылке буква $\tau$ с одной точкой, в заключении - с двумя.

Последний модус первой фигуры состоит из частноутвердительной меньшей посылки и из общеотрицательной большей посылки (Ferio).

Некие эфиопь - грамматики

Никакой грамматик не говорит с ошибками

Сл., не всякий эбиоп говорит с ошибками

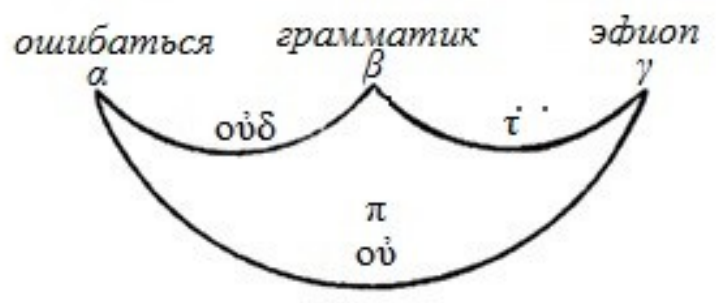

Рисунок 4 
Заметим, для обозначения посылок по количеству и качеству используются не гласные $(a, e, i, o)$ как принято на латинском Западе, а следующие сочетания:

- общая утвердительная: $\pi$ (от греч. $\pi \tilde{\alpha}$ — 'все')

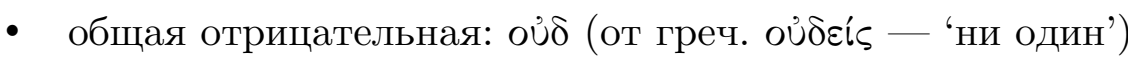

- частная утвердительная: $\tau \dot{\tau}, \dot{\tau}$ ' (от греч. $\tau i \varsigma^{\prime}$ 'некто')

- частная отрицательная: $\pi$

$$
\text { oủ }
$$

\section{Вторая фигура категорического силлогизма}

Здесь, при переходе ко второй фигуре, рисунок из трех дуг (который можно считать треугольником с изогнутыми сторонами) неожиданно переворачивается и сочетается с обычным треугольником, а буквы для обозначения трех терминов меняются на $\mu, \nu, \xi$, средний термин обозначается буквой $\mu$ и становится вершиной треугольника, вывод - основанием треугольника (Nikephoros Blemmydes 1863: 953-954).

В первом модусе второй фигуры меньшая посылка общая и утвердительная, большая общая и отрицательная (Cesare):

Всякий человек - животное

Камень не есть животное

Следовательно, человек не есть камень

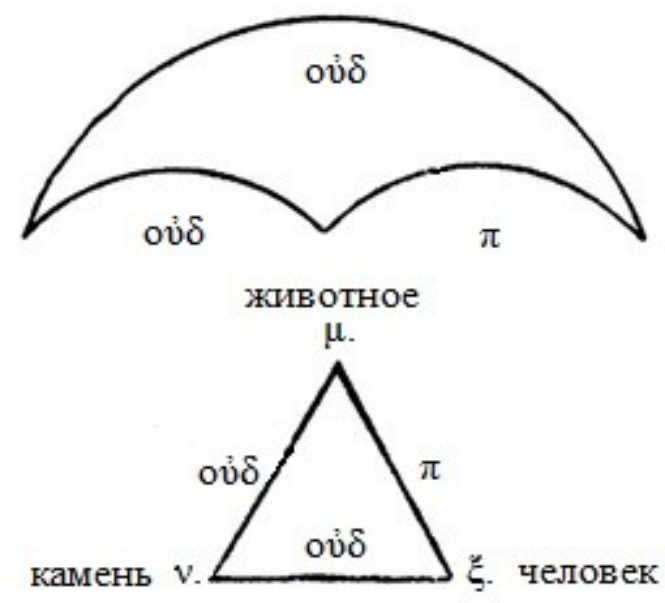

Рисунок 5

Второй модус второй фигуры - из общей и отрицательной меньшей посылки и общей и утвердительной большей посылки (Camestres):

Камень не животное

Человек - животное

Следовательно, камень не человек 

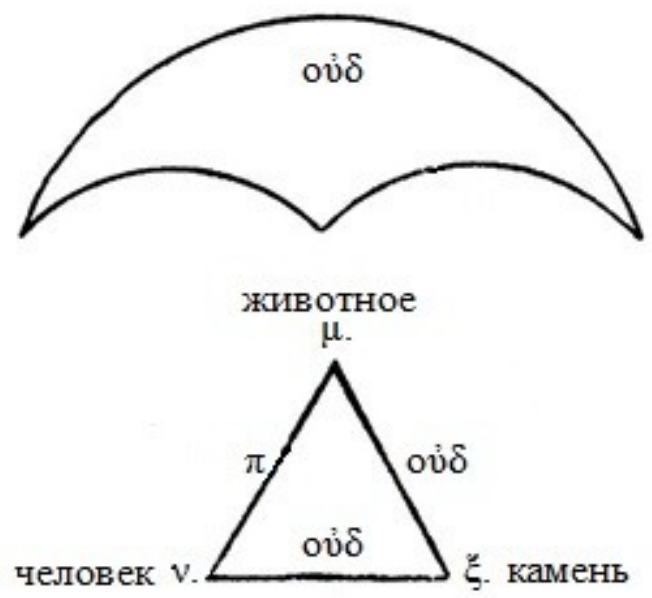

Рисунок 6

Третий модус второй фигуры: меньшая посылка - частная и утвердительная, большая - общая и отрицательная (Festino):

Некоторые животные разумные

Никакое неразумное не есть разумное

Следовательно, не все животные есть неразумные
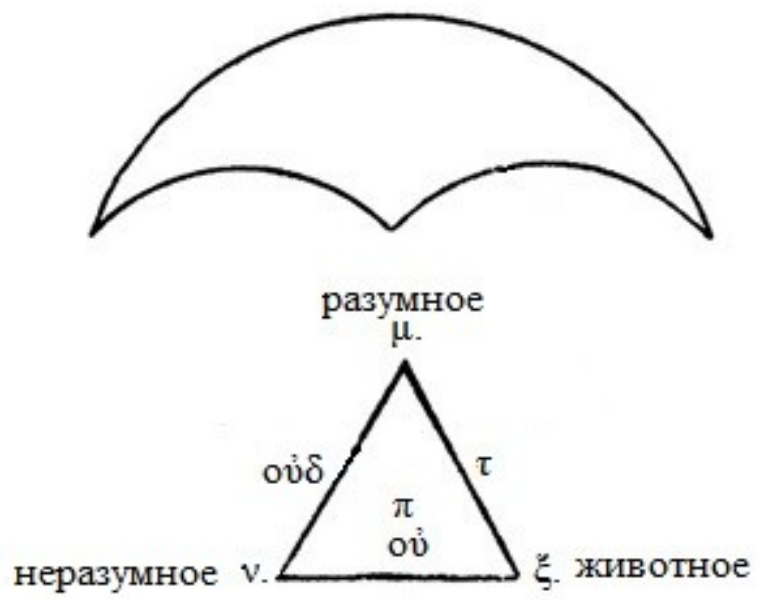

Рисунок 7

Четвертый модус второй фигуры - из отрицательной и частной меньшей посылки и утвердительной и общей большей посылки (Baroco):

Не всякое белое - животное

Всякий человек - животное

Следовательно, не всякое белое - человек 

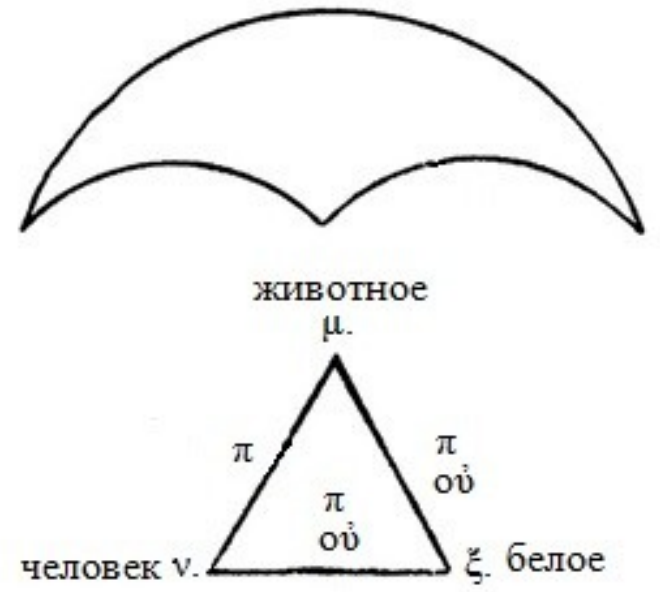

Рисунок 8

\section{Третья фигура категорического силлогизма}

Третья фигура графически отлична от первой и второй: относительно второй она перевернута, кроме того, три термина принимают обозначения трех следующих букв греческого алфавита $\pi, \rho, \sigma$, несмотря на то что $\pi$ уже занята для обозначения общности.

Первый модус третьей фигуры - из двух общих утвердительных посылок с утвердительным частным заключением (Darapti):

Всякий человек - животное

Всякий человек - разумен

Следовательно, некое животное - разумно
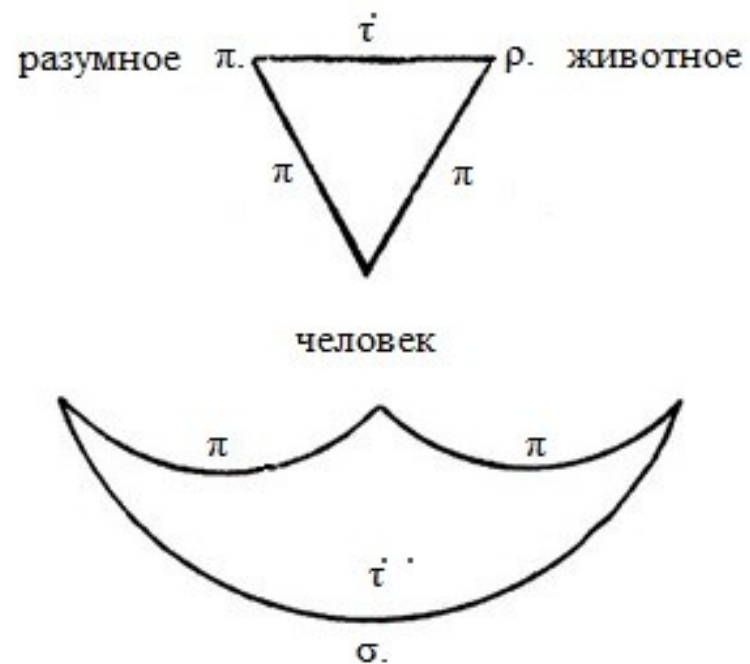

Рисунок 9

Второй модус третьей фигуры - из меньшей общей утвердительной и из большей общей отрицательной посылки получается частное отрицательное заключение (Felapton): 
Всякий снег бел

Никакой снег не животное

Следовательно, не всякое белое - животное

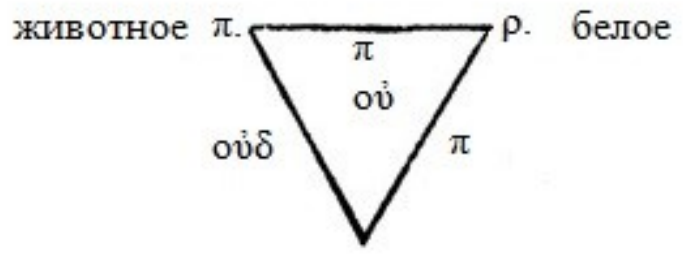

cHer

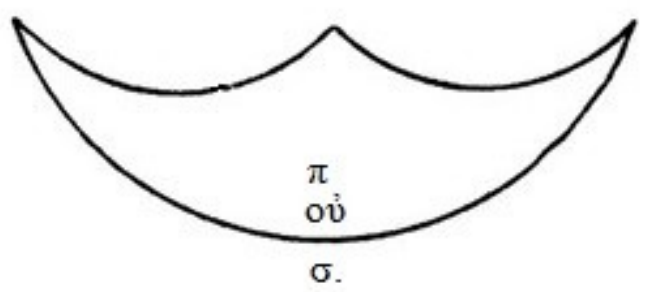

Рисунок 10

Третий модус третьей фигуры - из меньшей частной утвердительной посылки и большей общей утвердительной получается частное утвердительное заключение (Datisi):

Некий человек черен

Всякий человек - животное

Следовательно, некое черное есть животное

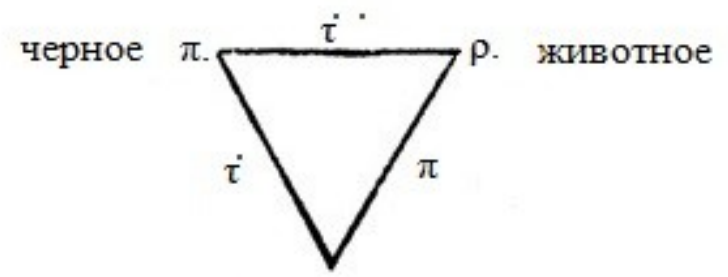

человек

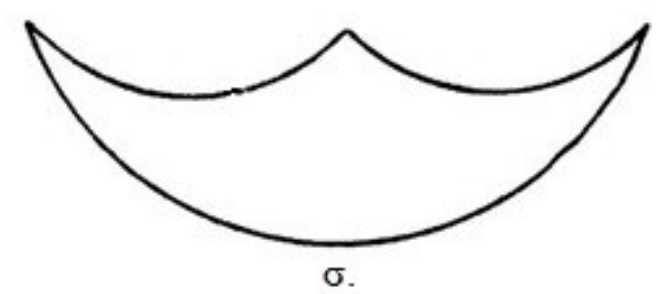

Рисунок 11

Четвертый модус третьей фигуры - из меньшей частной утвердительной посылки и большей общей отрицательной посылки заключение получаем частное отрицательное (Ferison). 
Лариса Тоноян. О соотношении византийской и западной логических традиций

Некий каменъ бел

Камень не животное

Следовательно, некое белое не животное

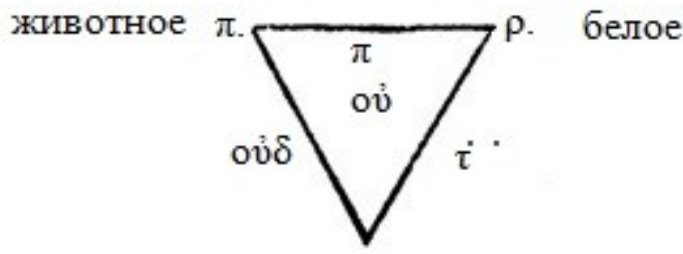

камень

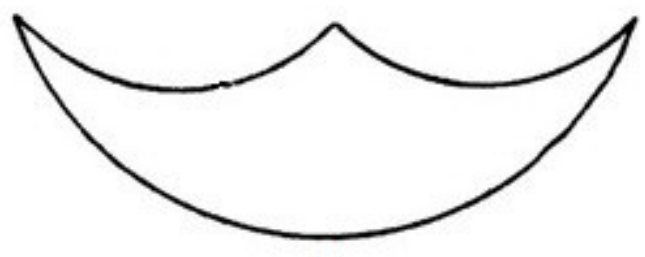

$\sigma$.

Рисунок 12

Пятый модус третьей фигуры - из общей утвердительной меньшей посылки и частной утвердительной большей посылки заключение получается частное утвердительное (в приведенном примере большая посылка стоит на первом месте, как в Disamis):

Всякий человек - животное

Некий человек бел

Сл., некое животное - белое

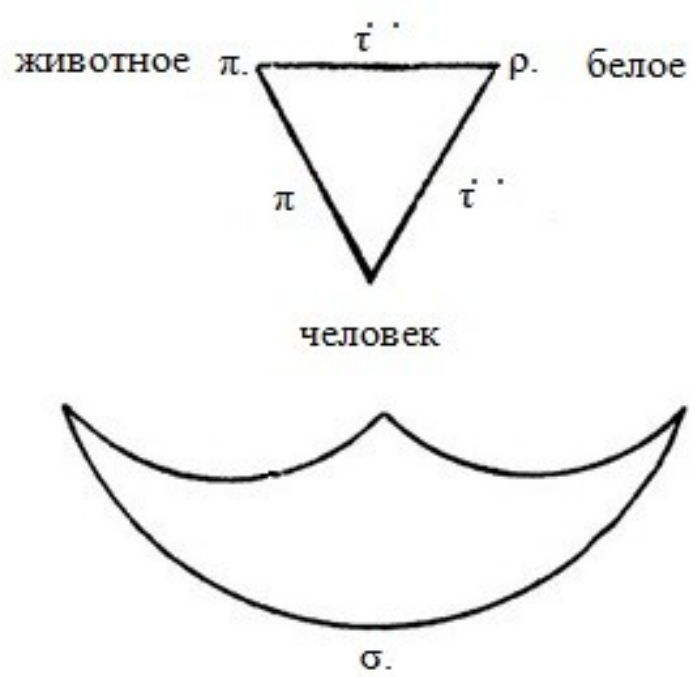

Рисунок 13

Шестой модус третьей фигуры - из общей утвердительной меньшей посылки и частной отрицательной большей посылки заключение получаем частное отрицательное (Baroco): 
Всякий человек - животное

Не всякий человек черный

Следовательно, не всякое животное черное

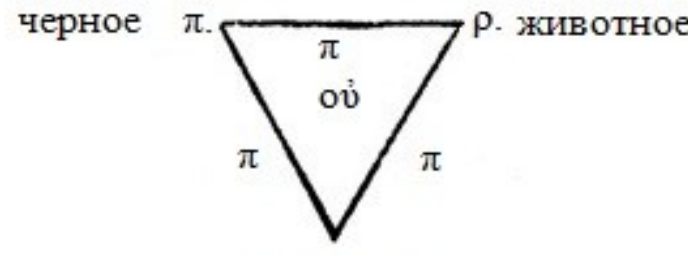

человек

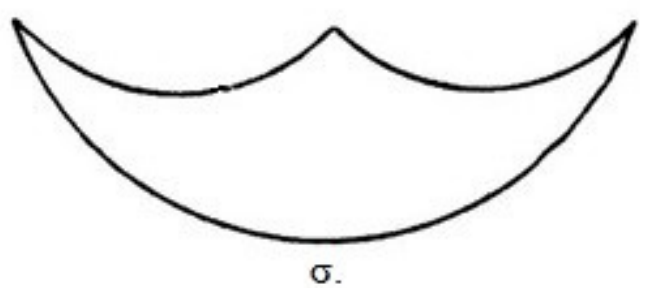

Рисунок 14

Никифором подробно рассмотрены все три фигуры со всеми 14 модусами, далее излагается сведение всех модусов второй и третьей фигур к модусам первой фигуры прямым и косвенным доказательством. Любопытно, что в греческом тексте нет ни латинских, ни греческих названий модусов силлогизма, зато, излагая категорический силлогизм, автор активно использует наглядные графические средства, в частности дуги и треугольники. Причем, чтобы отличить одну фигуру от другой, первую, как главную, он изображает только тремя дугами, во второй рисунок переворачивается и дополняется треугольником, а третья фигура - перевернутая вторая.
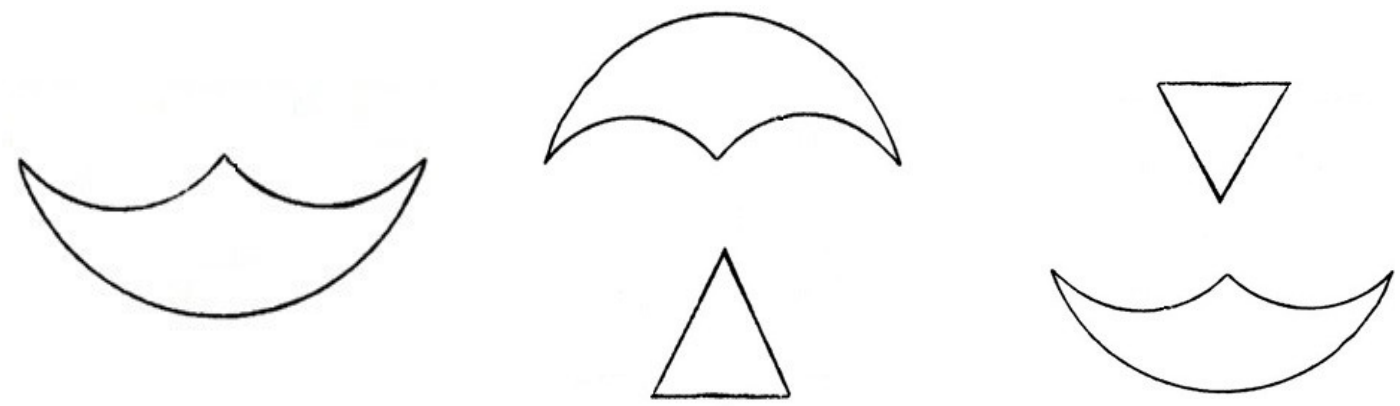

Рисунок 15. Первая фигура

Рисунок 16. Вторая фигура

Рисунок 17. Третья фигура

Примечательно то, что у Влеммида нет пяти теофрастовских модусов. У него только три фигуры с 14-ю правильными модусами, а не четыре фигуры с 19-ю модусами, как в латинских учебниках XIII в. Но главной особенностью изложения категорического силлогизма у Влеммида являются буквенные обозначения и графических фигуры, которых ни в учебниках Петра Ис- 
панского (Peter of Spain 1972), ни в учебниках других средневековых латинских авторов нами не обнаружено. По всей видимости, Влеммид использовал более ранние и притом исключительно греческие источники.

\section{Влияние на логическое образование}

Скорее всего, в учебнике Влеммида мы имеем дело с византийской традицией изложения учения о категорическом силлогизме, подтверждение чему мы обнаружили в учебнике Георгия Трапезундского. Георгий Трапезундский (1395, Крит - приблизительно 1473, Рим) принадлежит к числу тех греков, которые ушли из распадающейся Византии, и пришли на Запад, обогатив его культурой Востока и став первыми представителями итальянского Возрождения. Он написал в 1439-1440 гг. трактат «Диалектика» (Trapezuntius 1523), ставший, как считают, первым в истории Ренессанса учебником по логике. Написал он его на латинском языке, но пользовался, по всей видимости, в основном греческими рукописями. В его изложении логики мы замечаем влияние учебника Влеммида. Косвенным, а может быть прямым, подтверждением могут служить рисунки и обозначения, почти полностью совпадающие с рисунками в учебнике Никифора Влеммида, которого он, правда, не называет.

Мы видим на примере первого модуса, что рисунок почти тот же, термины те же, знаки для посылок даны в переводе на латинский язык (буква О вместо $\pi)$, но, при этом, добавляется латинское название модуса - Barbara - и меняется порядок посылок (Trapezuntius 1523: 66).

\begin{tabular}{|c|c|c|}
\hline O (Omnis) & знак для & "Все есть" \\
\hline N (Nullus) & знак для & "Ничто не есть" \\
\hline Q (Aliquis) & знак для & "Некоторые есть" \\
\hline $\mathrm{Q}^{\cdot}$ (Aliqs. Non) & знак для & "Некоторые не есть" \\
\hline
\end{tabular}

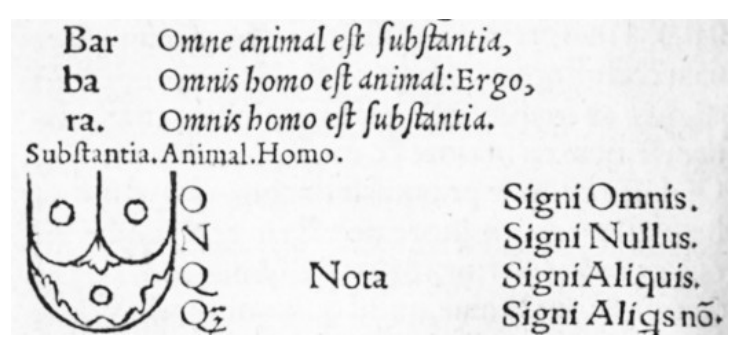

Эти рисунки вызывают вопрос: зачем Георгий использует переведенные с греческого языка латинские буквы $\mathrm{O}, \mathrm{N}, \mathrm{Q}, \mathrm{Q} \cdot$ · , если у него в названиях но дусов уже приведены латинские буквы $a, e, i, o$. Видимо, это свидетельство того, что Георгий компилятивно соединял греческое и латинское изложение. В отличие от учебника Влеммида, в учебнике Георгия к первой фигуре добавлены пять теофрастовских модусов с их рисунками. Для второй и третьей фигуры Георгий использует только треугольник, без дуг. 


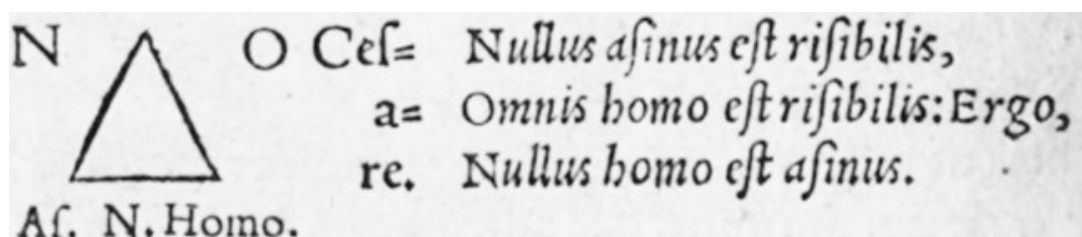

Сравнивая эти два трактата, мы обнаруживаем еще одно сходное изложение, а именно, сведение к первой фигуре, и, в особенности, изложение процедуры сведения к невозможному. Влеммид подробно с примерами сводит десять модусов второй и третьей фигур к модусам первой фигуры сначала прямо, потом косвенно (сведением к невозможному).

Здесь он уже не пользуется рисунками. А вот у Георгия Трапезундского и сведение иллюстрируется рисунками, к примеру, так выглядит сведение Darapti третьей фигуры к Darii первой фигуры:

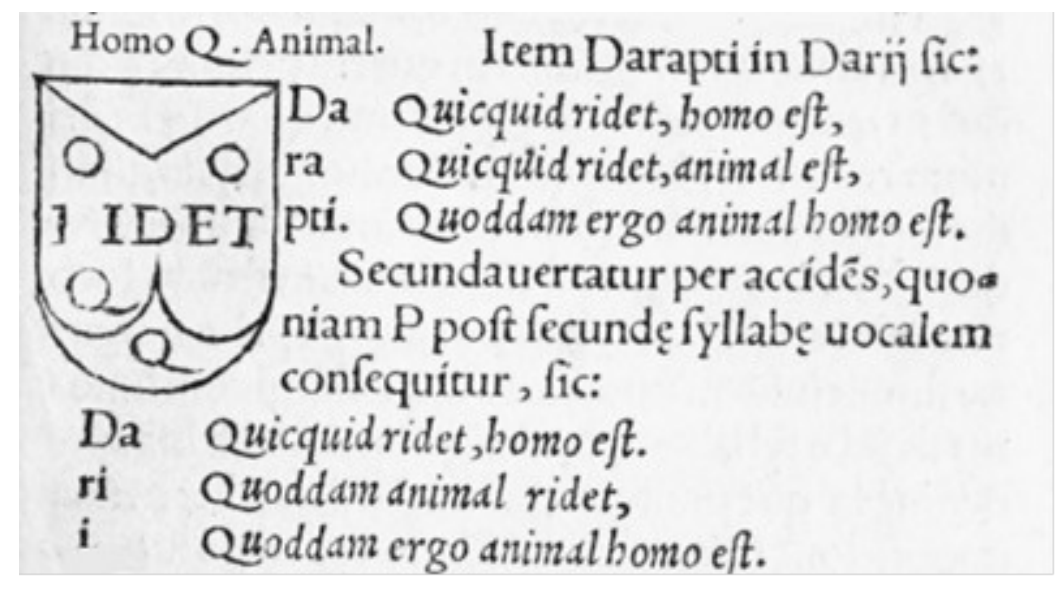

При этом у Влеммида вся эта процедура сведения описывается подробно и полно, а Георгий быстро завершает тему, решив не приводить примеры данной процедуры для всех остальных модусов.

По всей видимости, Георгий пользовался не только учебником Влеммида. Треугольник - фигура вполне органичная для силлогизма, основной принцип которого - опосредованность, транзитивность, троичность, поэтому его появление в разных вариантах схем силлогизма вполне предсказуемо.

Надо отметить, что учебник Георгия получил немалую популярность. Первое, венецианское, издание Isagoge Dialectica появилось в 1470 году; и за следующие 60 лет он был издан более пятидесяти раз. К сожалению, Георгий также не называет прямо свои источники, хотя и упоминает «перипатетические источники» и часто жалуется на некомпетентность переводчиков сочинений перипатетиков.

\section{Заключение}

Известный медиевист Ст. Еббесен в своем анализе «Логики» Влеммида (Ebbesen 2008: 141-144) неслучайно отмечает, что в ней нет влияния западных источников. В результате завоевания Константинополя латинянами в 
Никейской империи значительно возрос интерес к Платону и Аристотелю. Влеммид больше примыкал к аристотеликам, чем к платоникам, но испытал серьезное влияние неоплатоников. Как уже сказано, источниками для Влеммида служили комментарии к логике Аристотеля александрийских неоплатоников. Об этом можно судить также по учению о гипотетическом силлогизме, имеющемуся в данном трактате. Это учение, изложенное на латинском языке еще в VI в. Боэцием, почему-то полностью отсутствовало в латинских «Суммулах» Петра Испанского. При этом в учебнике Влеммида оно изложено подробно и опирается на труды неоплатоников, прежде всего Аммония и Филопона. Изложение Влеммида ближе к Аристотелю, чем в «Суммулах» Петра Испанского. В «Суммулах» учение о категорическом силлогизме изложено в Трактате IV (Peter of Spain 1972: 43-54). Никаких схем и даже букв для обозначений терминов мы там не находим. А в трактате Никифора не только приведены различные рисунки для каждой фигуры, но и использованы для каждой фигуры свои наборы греческих букв для обозначения терминов: для первой фигуры $-\alpha, \beta, \gamma$, для второй фигуры $-\mu, \nu, \xi$, для третьей фигуры $-\pi, \rho, \sigma$, т. е. именно те, которые использовал Аристотель. Далеко не все комментаторы и переводчики Аристотеля отображают эти особенности обозначения. Это свидетельствует о том, что Никифор опирался непосредственно на тексты Аристотеля, а не только его комментаторов, которые такие детали не принимали во внимание. Конечно, вышеприведенные рисунки не столь наглядны, как круги Эйлера, но весьма пригодны для мнемонических целей запоминания фигур и их модусов.

Соотнести христианское богословие с логикой и диалектикой в Византии, по-видимому, впервые попытался в VII-VIII вв. Иоанн Дамаскин. «Сокращенная логика» Влеммида продолжает выполнять эту задачу и дополняет ее. Если у Дамаскина, как уже было сказано, очень кратко излагается учение о категорических и гипотетических силлогизмах, то у Влеммида это учение преподается в подробной и наглядной форме.

Рассмотренное сочинение Влеммида стало любимым учебником не только на Востоке, но и на Западе: в греческих монастырях его переписывали даже в XVIII в., а в западноевропейских библиотеках хранятся списки XV, XVI и XVII вв.

Наш анализ учебников Влеммида и Георгия Трапезундского позволяет выдвинуть гипотезу о том, что аристотелевское учение о категорическом и гипотетическом силлогизмах (возможно, с графическими изображениями и мнемоническими правилами) было разработано перипатетиками и александрийскими неоплатониками, унаследовано и разработано византийскими логиками (в частности, Никифором Влеммидом), и лишь в дальнейшем получило свое завершение на Западе. 


\section{Литература}

Св. Иоанн Дамаскин 2006 - Св. Иоанн Дамаскин. Философские главы // Источник знания. СПб.: Наука, 2006. С. 7-76.

Никифор Влеммид 2003 - Никифор Влеммид. Царская статуя / пер. Л. С. Ряшко // Византийский временник. 2003. Т. 62 (87). С. 283-321.

Никифор Влеммид 1969 - Избранные места из автобиографии монаха и пресвитера Никифора, ктитора / пер. с греч. Л. А. Фрейберг // Памятники византийской литературы IX-XIV веков. М.: Наука, 1969.

Платон 1971 - Платон. Государство // Сочинения в трех томах. Т. III, ч. 1. М., 1971.C. 89-454.

Ebbesen 2008 - Ebbesen S. Greek-Latin Philosophical Interaction. Vol. 1. SAXO Institute, University of Copenhagen, Denmark, 2008.

Nikephoros Blemmydes 1863 - Nicephori Blemmidae Epitome Logica // Patrologiae Cursus Completus. Series Græca / ed. J. P. Migne. V. 142. 1863. Col. 675-1005. URL: https://books.google.ru/books?id=yfQUAAAAQAAJ (дата обращения: 30.12.2019).

Peter of Spain 1972 - Peter of Spain. Tractatus, Called Afterwards Summule Logicales / ed. by L. M. de Rijk. Assen: Van Gorcum, 1972.

Trapezuntius 1523 - Georgii Trapezuntii De re dialectica liber ac. Lugduni: apud Antonium Vincentium, 1523. URL: https://babel.hathitrust.org/cgi/pt? id=ucm.5317949429 (дата обращения: 30.12.2019). 